mer (two-year-old birds) suggest that some at least pass through Vancouver in migration, and again some may remain for the summer. As yet we have no Vancouver sightings for the fourth summer (three-year-olds) and only one, possibly early in fall migration, from the fifth year.

A small amount of additional information may be gleaned from records of three of my California Gulls that returned to the prairies in succeeding years. A California Gull, banded at Last Mountain Lake on June 23, 1958, returned in its fifth summer (as a four-year-old) to the same lake on May 21, 1962-at an age when we would expect it to return to its native lake to breed. There are also two records of California Gulls banded at Redberry Lake in June, 1960, that returned to the prairies in their third summer as two-year-olds: one was found dead at Drumheller, Alberta, on June 20, 1962, and one at Parkbeg, Sask., reported in a letter of July 22, 1962. Since neither had returned to its lake of origin, it is possible that they were non-breeding wanderers.

More distant recoveries remain comparatively few, but all are from localities along the Pacific Coast:two from California, three from Sonora, one from Sinolca, and one from Baja California (the last five in Mexico). These numbers are rather insignificant when compared with the Vancouver observations.

It is obvious that the careful observations and long hours expended by $R$. F. Oldaker have produced valuable results. He deserves wide recognition, for he has amply demonstrated the efficacy of his method. Although it is doubtful whether anyone else will read a fraction of the number of bands that he has, we can nevertheless hope that similar studies of other suitable species will result in years to come. Not only is $\mathrm{Mr}$. Oldaker adding steadily to our knowledge of gull migration every year, but he has even induced some banders to mend their. ways-for after the haphazard application of bands to twenty-thousand-odd birds, I am now careful to apply all bands with the numbers right-side-up!

\section{BIBLYOGRAPHY}

Hughes, W. M. 1960. Seven years of banding Glaucous-winged Gulls. News from the Bird Banders, 35: 42-46.

Kirshir, William K. 1963. About Mr. Oldaker. Western Bird Bander, $38: 7$.

Moos, Louis M. 1962. Report of gull banding in Montana. Western Bird Bander, 37:3941.

oldaker, R. F. 1960. A survey of the California Gull carried out in 1959. News from the Bird Banders, 35:30-31.

. 1960. Band reading by telescope. News from the Bird Banders, 35:39-42.

Western 1961. Survey of the California Gull, Western Bird Bander, 36:26-30.

Californi 1963. Sight records of banded California Gulls, Western Bird Bander, 38:
$7-10$.

\title{
Gray-crowned Rosy Finch at Fort Qu'Appelle
}

by E. Manley Callin, Fort San

On February 2, 1963, an alert observer, Dr. Harley D. Jenner of Fort San, telephoned to report that there were two unusual birds at his feeding station and they could not be found in his bird book (Peterson's eastern guide). Armed with Peterson's western guide, I called at the Jenner home the next day and was rewarded with a close view of the first Gray-crowned Rosy Finches (Leucosticte tephrocotis) I had ever seen.

The two birds, both males, first appeared on February 2 and, with their unusual but beautiful combination of brown, rose and gray colors, regularly graced the Jenner's feeding station for the next two months. If a fairly close watch was maintained, they could be seen half a dozen times a day, sometimes two birds and sometimes only one. The last bird was seen on April 3, but there was never more than one bird seen at any one time after March 15 and this of course posed unanswerable questions to to whether both birds were still present, whether one had left or whether one had fallen to a predator.

It is interesting to note that these or other birds may have been in the vicinity at an earlier date. Dr. A. L. Swanton has described a bird seen at Fort San on January 21, 1963, which 
I am satisfied was a Rosy Finch, and Dr. A. J. Hughes of Fort Qu'Appelle apparently saw one on his premises on two different days at approximately this time. Both observers were attracted by the light, yellowish bill which contrasted with that of the House Sparrows which were also present.

Four Regina enthusiasts, Margaret Belcher, Marjorie Ledingham, Lucy Murray and Holly Wallace, came out to Fort San on March 9 and the birds co-operated beautifully. Dr. and Mrs. Jenner were supplying a mixture of ground suet, peanut butter and sometimes cracked grain in a feeder on a window sill and the birds were tame enough that an observer on the inside could watch them from a distance of probably ten feet and sometimes less. The Regina group watched them for almost an hour as they came once or twice to feed on the window sill or as they fed on seeds in the flower garden at the base of the hill beside the house.

Dr. and Mrs. Jenner have made the following interesting observations concerning their feathered visitors:

(a) From the beginning they were fairly tame but as the weeks went by the birds became even more confiding.

(b) When feeding they were usually in competition with the House Sparrows and showed considerable aggressiveness; on only one cccasion was a sparrow seen to contest the issue.

(c) During the last few weeks that they were present, the rosy colour of the birds became brighter and more easily seen.

As most of our readers will know, the normal home of the Rosy Finch is in the mountains of Western Canada and United States and it is rarely seen in Saskatchewan. Evidence of this is indicated by the following recorded observations:

May, 1827-specimen taken near the Saskatchewan River between Saskatoon and Prince Albert (probably near Carlton).

November 26, 1921, January 20, 1922, and March 16, 1922-specimens taken at Eastend. Noted in several years.

Prior to 1924 -repeated observations at Indian Head.

March 1, 1933-"many seen" at Ravenscray (Spencer Pearse).

January, 1934-"bands" at Eastend (L. B. Potter)

February 26, 1934-specimen taken at Dollard by Charles F. Holmes.

October 23, 1940-sight record of one bird at Regina.

Ea:ly December, 1940-one seen for several days in Nipawin area.

Early winter, 1948-specimen taken at Regira.

June 3, 1953-sight record of one bird in Nipawin area.

October 20, 1962-sight record of one bird at Saskatoon.

February 2 - April 3, 1963-two males observed regularly in Fort Qu'Appelle area.

Details of the various observations may be found in The Birds of the Saskatchewan River (Houston and Street, 1959), Catalogue of the birds of Saskatchewan (Mitchell, 1924), Birds of Regina (Belcher, 1961), in the Blue Jay (21:12), in the references which those publications have quoted, and in the SMNH files.

It will be noted that there have been only six recorded observations in Saskatchewan in the last 25 years or more. This winter we have other reports from outside Saskatchewan of Rosy Finches east of their usual range. In southwestern South Dakota (Black Hills area) they appeared mid-January to mid-February, with 80 counted by L. Baylor near Hill City, South Dakota, on February 17, 1963; and near Lethbridge, Alberta, T. H. Bassett sighted one on March $30,1963$.

\section{First Record of Wood Duck for Regina Area}

\section{by Margaret Belcher and Doug Gilroy, Regina}

On November 24, 1962, Albert Swanston of the Saskatchewan Museum of Natural History, found a female Wood Duck (Aix sponsa) in one of his mink traps along the Boggy Creek, three-quarters of a mile from the buildings on Doug Gilroy's farm 14 miles northwest of Regina. The duck was removed from the trap and shown to Doug Gilroy, and it was identified as a Wood Duck. This duck is considered rare in any part of the prairies, and neither Swanston nor Gilroy had seen one before, so several bird books were brought out io confirm the identification. The duck was then submitted to the Saskatchewan Museum of Natural History for preparation as a study skin.

The summer range of the Wood 